\title{
Cervical Subcutaneous Emphysema and Pneumomediastinum Caused by Perforated Diverticulitis
}

Leticia Pérez Santiago, Rafael Cholvi Calduch, Rosa María Martí Fernández and *Marina Garcés Albir Department of General Surgery, Spain

Received: October 30, 2018; Published: November 15, 2018

*Corresponding author: Marina Garcés Albir, Department of General Surgery, Hospital Clínico Universitario de Valencia, Avd Blasco Ibañez, 17 46010 Valencia, Spain

Keywords: Pneumomediastinum; Subcutaneous emphysema; Perforated diverticulitis

Clinical Image

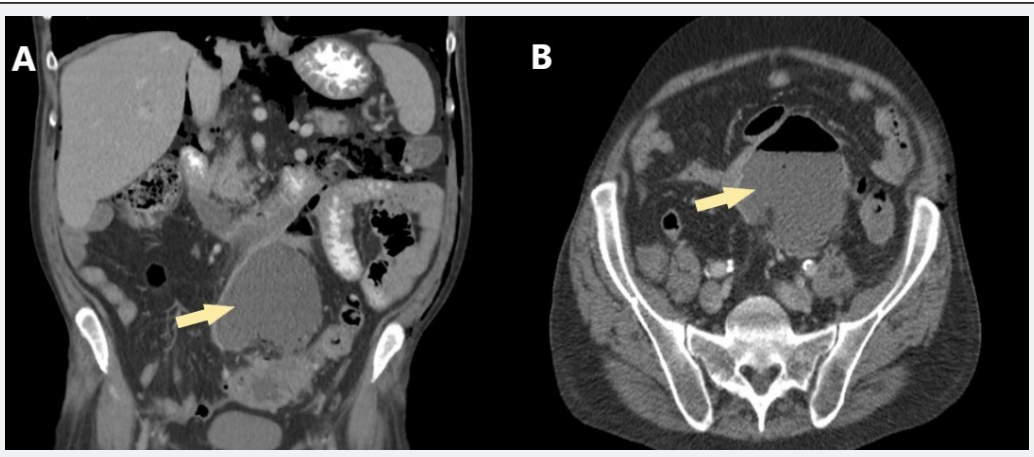

Figure 1: Coronal (A) and axial (B) abdominal CT scan shows an intraabdominal abscess (yellow arrow) and unstructured mesosigmoid due to perforated diverticulitis.

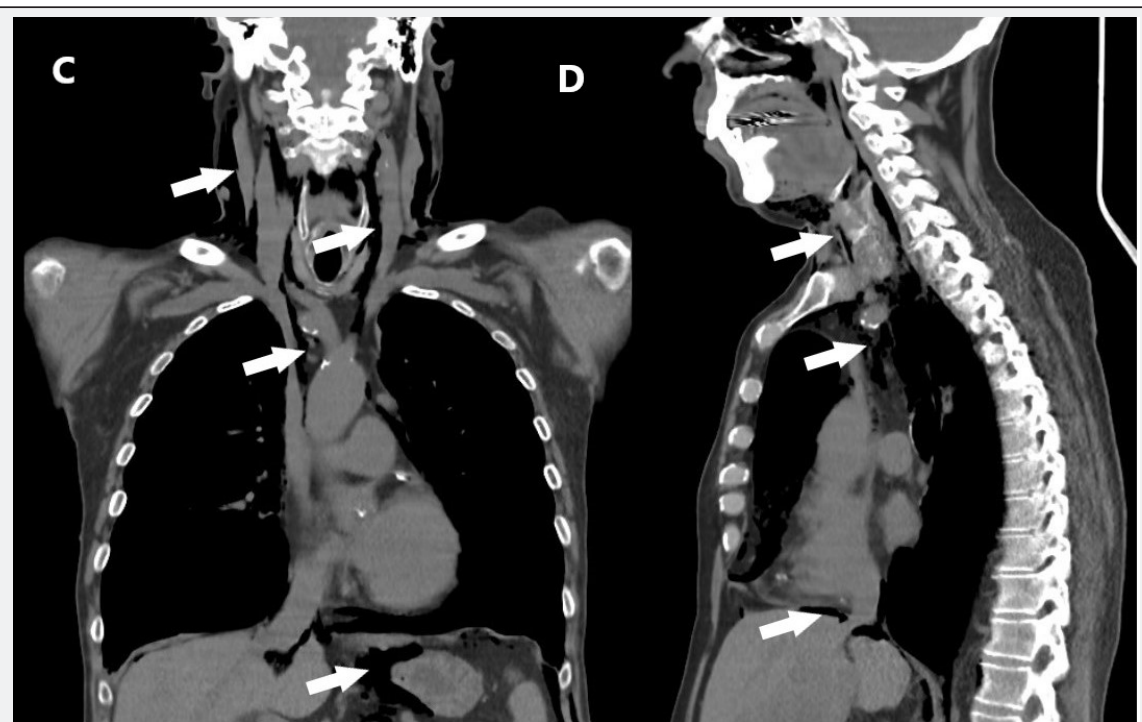

Figure 2: Coronal (A) and axial (B) cervicothorax abdominal CT scan with pneumoperitoneum, pneumothorax, retropenumoperithoneum and cervical subcutaneous emphysema (white arrows). 


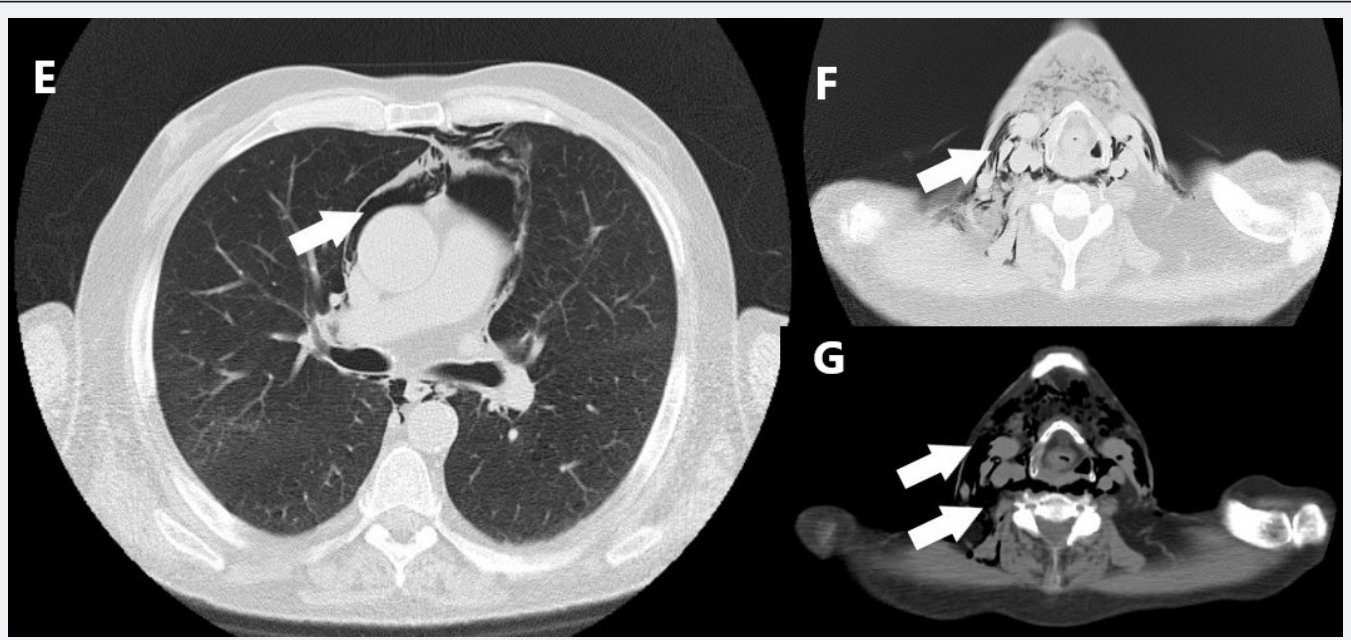

Figure 3: Coronal (E, F, G) cervicothorax CT scan: extensive pneumomediastinum and cervical subcutaneous emphysema (white arrows).

Diverticular disease is a digestive pathology very frequent in the emergency departments. The most common symptom is abdominal pain [1]. However, cervical subcutaneous emphysema and pneumomediastinum [2,3] are rare clinical presentations, whose knowledge is interesting in clinical practise. A 59-year-old man with IV stage lung cancer arrived at emergency room with painful swallowing and foreign body sensation in his thorax. On physical examination, patient presented cervical and thoracic subcutaneous emphysema and abdominal pain without signs of peritoneal irritation. CT scan showed extensive abscess with diverticular disease and parietal thickening of the sigma [Figure 1]. Extensive pneumomediastinum, pneumoperitoneum, retro pneumoperitoneum and cervical subcutaneous emphysema were also shown (Figures $2 \& 3$ ).

During surgical exploration we found a perforated diverticulum with abscess and peritoneal carcinomatosis. Biopsies and sigma resection with colostomy were performed. The pathology report described diverticular disease and peritoneal carcinomatosis secondary to pulmonary neoplasia. At the end, he died 20 days after surgery.

\section{References}

1. Mora López L, Flores Clotet R, Serra Aracil X, Montes Ortega N, Navarro Soto $S$ (2017). Aplicación de la clasificación de Neff modificada en el manejo de la diverticulitis aguda. Rev Esp Enferm Dig; 109: 328-334.

2. Garay Burdeos JM, Marcóte Valdivieso E, Romero Simó M, Giner Nogueras M, Canales López M, Torner Pardo A (1996). Enfisema cutáneo cervical como primera manifestación de una diverticulitis sigmoidea perforada. Cir Esp; 59: 361-362.

3. Hur T, Chen Y, Shu GH, Chang JM, Cheng KC (1995). Spontaneus cervical subcutaneus and mediastinal emphysema secondary to occult sigmoid diverticulitis. Eur Respir J; 8: 2188-2190.

Your next submission with Juniper Publishers
will reach you the below assets
- Quality Editorial service
- Swift Peer Review
- Reprints availability
- E-prints Service
- Manuscript Podcast for convenient understanding
- Global attainment for your research
- Manuscript accessibility in different formats
( Pdf, E-pub, Full Text, Audio)
- Unceasing customer service
Track the below URL for one-step submission
https://juniperpublishers.com/online-submission.php

